\title{
Coral (Anthozoa: Scleractinia) Recruitment at Bahías de Huatulco, Western México: Implications for Coral Community Structure and Dynamics $^{1}$
}

\author{
R. A. López-Pérez,, ${ }^{2,3}$ M. G. Mora-Pérez, ${ }^{2,4}$ and G. E. Leyte-Morales ${ }^{2}$
}

\begin{abstract}
Over the past decades there has been an increasing awareness of community structure and dynamics in eastern Pacific coral reef systems, yet the processes producing these patterns are poorly known. We conducted a quantitative analysis of patterns of sexual and asexual recruitment through fragmentation at six localities in Huatulco, México. Between January 2001 and January 2002, sexual recruitment was evaluated by using terracotta tiles. Fragmentation was addressed twice using quadrats. Two hundred ninety-two corals (291 Porites panamensis Verrill, 1 Pocillopora sp.) were recruited to the settlement tiles. Changes in abundance of recruits among sites were determined by coral cover of $P$. panamensis at each area. Fragmentation was restricted to Pocillopora spp., and processes producing fragments had no connection with those promoting their reattachment and survival. Sexual and asexual recruitment patterns and potential survival asymmetries displayed by $P$. panamensis and Pocillopora spp. in the area are of capital importance in the occurrence of local communities and potentially of those of the entire eastern Pacific region. Sexual and asexual recruitment patterns suggest that recovery of frame-building corals following disturbance is highly species-specific. Recovery of $P$. panamensis following coral removal can be relatively fast, but greatly prolonged for Pocillopora; however, in communities with low to moderate disturbance where patches of Pocillopora were preserved reef recovery can proceed at a moderate to relatively fast pace following disturbance. Coordinated multidisciplinary and interinstitutional efforts, including genetic, histological, and ecological approaches, are necessary to determine unequivocally the processes controlling community structure and dynamics in the area.
\end{abstract}

\footnotetext{
${ }^{1}$ The project (Reclutamiento sexual, fragmentación y bioerosión de las comunidades coralinas de Bahías de Huatulco) within which this work was done was funded by the Universidad del Mar, Puerto Ángel, México to R.A.L.P. Andrés López and M.G.M.P. were supported by a Consejo Nacional de Ciencia y Tecnología de México (CONACYT) Doctoral and Master Fellowship. Manuscript accepted 7 September 2006.

${ }^{2}$ Instituto de Recursos, Universidad del Mar, Puerto Ángel, Oaxaca, C.P. 70902, A.P. 47, México.

${ }^{3}$ Corresponding author (phone/fax: 958-584-3057, 49, 78; e-mail: alopez@angel.umar.mx).

${ }^{4}$ Current address: Instituto de Pesquerías, Centro Interdisciplinario de Ciencias Marinas, La Paz, B.C.S., México.
}

Pacific Science (2007), vol. 61, no. 3:355-369 (C) 2007 by University of Hawai'i Press

All rights reserved
IN GENERAL, SEXUAL and asexual recruitment are the means by which corals maintain their populations. Populations release swimming larvae that are carried by currents to settle and colonize new habitats, as well as to maintain the native reefs from which they were released (Sammarco 1994). Long-distance dispersal of swimming larvae can act as a means to establish remote and nearby new reefs, and promote gene flow (Scheltema 1977, Ayre and Hughes 2000). Locally, larvae can maintain local populations and, depending on the extent and severity of the damage, recolonize old reef patches after disturbance (Fox 2004).

In coral reefs, though asexual replication and settlement might occur through asexual larvae, fragmentation is considered the dominant asexual process (Richmond 1997). Frag- 
mentation occurs among many branching and nonbranching species when intact colonies are broken apart, especially by bioerosion, predation, storms, and hurricanes (Reyes-Bonilla and Calderón-Aguilera 1994, Glynn et al. 1998, Lirman et al. 2001). Under favorable conditions, fragments may survive, reattach to the substrate, and reproduce. Fragmentation potentially allows species and genets (all colonies derived from the same sexual recruit) to extend their distribution and abundance locally, producing patches of adjacent clones (Hunter 1993). In addition, fragments are able to reach sites where larvae are unable to settle, such as sandy areas at the periphery of a coral reef (Highsmith 1980). Furthermore, because live coral fragments may move up to tens of meters due to water movement or gravity (Dollar and Tribble 1993), fragmentation is extremely valuable in the shortterm recovery of local populations following disturbance. Unfortunately, the cost of fragmentation in corals can be high. Especially during mass-mortality episodes, overall rate of mortality could be higher than that of a nonfragmented genet (Smith and Hughes 1999), resulting in the local or regional extirpation of species or genets.

The importance of recruitment in the structure and dynamics of coral populations and communities has received much attention during the past decades (Birkeland 1977, Connell et al. 1997, Richmond 1997). It is known, for instance, that larvae respond to settlement cues (Benayahu and Loya 1984, Maida et al. 1995, Mundy 2000), which may have profound effects on juvenile and adult distribution and abundance patterns. In addition, variable rates of recruitment among species coupled with differential survival of larvae and juveniles have a capital role in the structure and dynamics of coral communities (Miller et al. 2000, Soong et al. 2003).

Coral recruitment has been widely studied in the Indo-Pacific and Caribbean (Smith and Hughes 1999, Edmunds 2000, Carlon 2002, Hughes et al. 2002, Tamelander 2002). On the contrary, eastern Pacific studies, especially those on sexual recruitment, have been sporadic (Birkeland 1977, Wellington 1982, Richmond 1985, Medina-Rosas et al. 2005), and recruits have been extremely low. Due to the sporadic nature of eastern Pacific coral recruits, it has been suggested that coral species in the region might be sexually sterile (Richmond 1985, 1987, Ayre et al. 1997) and therefore eastern Pacific species rely fully on fragmentation to maintain their local populations (Birkeland 1977, Highsmith 1982, Wellington 1982, Richmond 1985, 1987, Glynn et al. 1996).

We examined the larval recruitment to settlement tiles and the asexual recruitment via fragmentation at several sites in the Huatulco area and looked for differences among species and localities. Here, we present data on recruitment rate and fragment recruitment from six coral communities in the Huatulco area. We hypothesize that modes of recruitment are conservative within but vary among coral species, and that any spatiotemporal asymmetry in recruitment and postsettlement mortality should be expressed in the coral reef community structure of Bahías de Huatulco.

\section{MATERIALS AND METHODS}

\section{Study Area}

This study was conducted at six locations in Bahías de Huatulco, western México (Figure 1): (1) La Tijera, $15^{\circ} 41^{\prime} \mathrm{N}, 96^{\circ} 26^{\prime} \mathrm{W}$; (2) Isla San Agustín, $15^{\circ} 41^{\prime} \mathrm{N}, 96^{\circ} 14^{\prime} \mathrm{W}$; (3) Jicaral-Chachacual, $15^{\circ} 42^{\prime} \mathrm{N}, 96^{\circ} 13^{\prime} \mathrm{W}$; (4) Isla Cacaluta, $15^{\circ} 43^{\prime} \mathrm{N}, 96^{\circ} 09^{\prime} \mathrm{W}$; (5) La Entrega, $15^{\circ} 44^{\prime} \mathrm{N}, 96^{\circ} 07^{\prime} \mathrm{W}$; (6) Isla Montosa, $15^{\circ} 45^{\prime} \mathrm{N}, 96^{\circ} 04^{\prime} \mathrm{W}$. Sixteen hermatypical species from three genera have been reported in the area, and most of the reefs exhibited high $(30-50 \%)$ to very high (60-90\%) live coral cover (Glynn and LeyteMorales 1997, Reyes-Bonilla and LeyteMorales 1998). The communities are dominated by Pocillopora spp., whereas poritids and agariciids are relatively uncommon or restricted to deep waters and do not contribute large amounts of carbonate material to the reef structure (López-Pérez and HernándezBallesteros 2004). Although it is probably one of the best-developed coral reef systems in western México (Reyes-Bonilla 2003), its species richness, species composition, and coral 

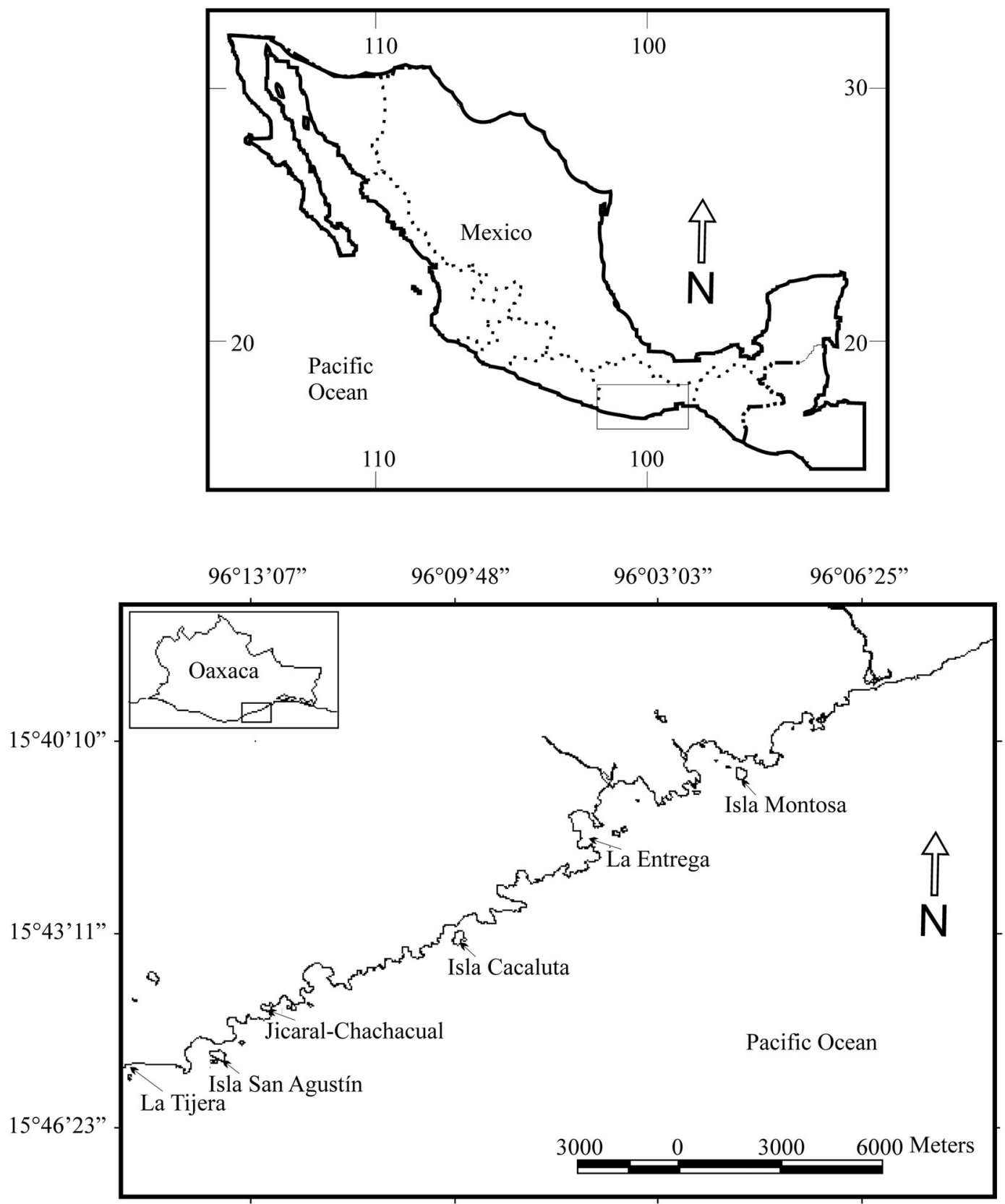

Figure 1. Study localities in the Bahías de Huatulco area, western México. 
coverage are frequently altered by environmental perturbations (Glynn and LeyteMorales 1997, Lirman et al. 2001, LópezPérez et al. 2002, Reyes-Bonilla et al. 2002, López-Pérez and Hernández-Ballesteros 2004).

\section{Coral Coverage}

Between November 2000 and October 2001, except for December and July, three monthly 50 by $1 \mathrm{~m}^{2}$ belt transects were conducted in San Agustín, Jicaral-Chachacual, Isla Cacaluta, La Entrega, and Isla Montosa, in the Huatulco area (Figure 1). All sampling transects (three per month per locality) were randomly placed in the reefs and ran parallel to the coastline at any depth, inside the bathymetric interval where reefs occur $(2-13 \mathrm{~m}$ [Glynn and Leyte-Morales 1997]). Along each transect, all underlying coral species at a $1-\mathrm{m}^{2}$ interval were recorded. In addition, substrate characteristics such as either rocks, sand, algal mat, or cemented coral cover (dead corals) were recorded.

\section{Larval Recruitment}

Six triangular iron structures, with two faces ( 1 by $1 \mathrm{~m}$ ) forming an angle of $45^{\circ}$ with respect to the ocean floor, were randomly interspersed at each community inside the bathymetric interval where reefs occur. To each iron structure, six terracotta settlement tiles $(28$ by 14 by $2.5 \mathrm{~cm}$ ) were attached to each face (12 tiles per structure) with plastic strings. Structures were submerged in January 2001 at Isla Montosa, La Entrega, and La Tijera and retrieved in December 2001 (the former two) and in January 2002 (the latter). At Isla Cacaluta and Jicaral-Chacacual, structures were submerged in February 2001 and retrieved in January 2002. Finally, at Isla San Agustín structures were submerged in March 2001 and retrieved in January 2002. The structures recorded a recruitment period of 11 months at Isla San Agustín; 12 months at Isla Montosa, La Entrega, Isla Cacaluta, and Jicaral-Chachacual; and 13 months at La Tijera. To investigate intra-annual variation in recruitment, two randomly selected tiles were replaced monthly at each locality. It was assumed that recruitment on the replacement tiles would proceed at the same pace as that on the remaining tiles (50 tiles) in the array; however this probably is untrue because it has been demonstrated that larvae respond to settlement cues (Mundy 2000) acquired during a potentially variable conditioning time (up to 5 months), as suggested by our study (see Larval Recruitment results).

Immediately after collection, the settlement tiles were labeled and all soft tissues were removed by immersing the tiles in hypochlorite solution. The plates were dried, all surfaces were examined, and the corals were identified under a dissecting microscope. Iron structures were treated as replicas in the subsequent data analysis.

Recruitment rate (ind $\mathrm{m}^{-2} \mathrm{yr}^{-1}$ ) was calculated for each locality. Because the data were neither normal nor homocedastic even after a square-root transformation, a nonparametric Kruskall-Wallis analysis of variance (ANOVA) was used to analyze the effect of locality on recruitment rate. Differences between localities were examined using a Dunn test for uneven sample size (Zar 1999) because the number of recovered structures varied between localities.

The diameter of each recruit was measured and the average diameter of each individual was plotted through size-frequency distributions of raw data. Because size data were neither normal nor homocedastic even after a logarithmic transformation, a nonparametric Kruskall-Wallis ANOVA was used to analyze the effect of locality on coral size. Differences between localities were examined using a Dunn test for uneven sample size (Zar 1999) because the number of recruits varied between localities.

\section{Asexual Recruitment}

Fragmentation was addressed twice (November and December 2001) at the periphery of each coral community. Two types of fragments were recognized, fragments and successful fragments. Fragments were defined as colonies with fractured surfaces characteristic of asexual reproduction (Highsmith 1982) but 
Coral Recruitment in the Mexican Pacific - López-Pérez et al.

TABLE 1

Live Coral Cover and Substrate Characteristics at Bahías de Huatulco Localities between November 2000 and October 2001

\begin{tabular}{|c|c|c|c|c|c|}
\hline $\begin{array}{l}\text { Species/Substrate } \\
\text { Characteristics }\end{array}$ & $\begin{array}{l}\text { Isla San Agustín } \\
\quad(n=24)\end{array}$ & $\begin{array}{c}\text { Jicaral-Chachacual } \\
\quad(n=27)\end{array}$ & $\begin{array}{l}\text { Isla Cacaluta } \\
\quad(n=26)\end{array}$ & $\begin{array}{l}\text { La Entrega } \\
\quad(n=35)\end{array}$ & $\begin{array}{l}\text { Isla Montosa } \\
\quad(n=22)\end{array}$ \\
\hline $\begin{array}{l}\text { Pocillopora damicornis } \\
\quad \text { (Linnaeus, 1758) }\end{array}$ & $59.6 \pm 25.3$ & $8.9 \pm 17.7$ & $30.4 \pm 20.8$ & $36.2 \pm 23.9$ & $6.6 \pm 9.3$ \\
\hline $\begin{array}{l}\text { Pocillopora capitata Verrill, } \\
1864\end{array}$ & $1.3 \pm 3.1$ & $0.3 \pm 0.5$ & $10.3 \pm 14.8$ & $1.1 \pm 2.6$ & $27 \pm 24.1$ \\
\hline $\begin{array}{l}\text { Pocillopora verrucosa (Ellis \& } \\
\text { Solander, } 1786)\end{array}$ & $2.6 \pm 4.8$ & $1.8 \pm 3.4$ & $20.8 \pm 17.8$ & $3.6 \pm 8.1$ & $1.8 \pm 2.8$ \\
\hline $\begin{array}{l}\text { Pocillopora eydouxi Milne } \\
\text { Edwards \& Haime, } 1860\end{array}$ & & & $0.1 \pm 0.2$ & & $6.6 \pm 13.3$ \\
\hline Pocillopora effusus Veron, 2000 & & & $0.1 \pm$ & & \\
\hline Porites panamensis Verrill, 1866 & $0.2 \pm 0.5$ & $0.4 \pm 0.5$ & $0.1 \pm 0.2$ & $0.1 \pm 0.2$ & $1.5 \pm 2.5$ \\
\hline Pavona gigantea Verrill, 1869 & $0.1 \pm 0.2$ & $0.2 \pm 0.6$ & & $0.1 \pm 0.4$ & $0.2 \pm 0.6$ \\
\hline Algal mat & $13.6 \pm 13.8$ & $45.6=$ & $9.3 \pm 18$ & $20.5 \pm 23.2$ & $1.4 \pm 2$ \\
\hline Death cover & $7.8=$ & 31.9 & $6.8 \pm$ & $29.2=$ & $9 \pm 16$ \\
\hline Sand & $8.6 \pm$ & $2.1 \pm$ & $12.5 \pm 13.3$ & $6.4 \pm 14.4$ & $24 \pm 25$ \\
\hline Rocks & $5.8 \pm 8.6$ & $8.8 \pm 15.3$ & $9.9 \pm 16$ & $2.7 \pm 6.6$ & $21.2 \pm 23.5$ \\
\hline Coral cover & 63.9 & 11.6 & 61.4 & 41.2 & 43.8 \\
\hline Substrate characteristics & 36.0 & 88.3 & 38.6 & 58.8 & 56.2 \\
\hline
\end{tabular}

Note: All values are mean species/substrate coverage \pm standard deviation. $n=$ number of transects.

unattached to the substrate; successful fragments were considered as previously defined but firmly attached to the substrate. This distinction was raised to distinguish between fragments that contribute to the coral population (i.e., successful fragments), compared with fragmentation affecting the population. Fragments and successful fragments were counted in $10\left(1 \mathrm{~m}^{2}\right)$ randomly placed quadrats per locality per time. When necessary, algae and sediments were brushed aside to locate corals, and colonies were identified to the lowest taxonomic level. Mean abundance of fragments and successful fragments was calculated for each locality. Because the data were neither normal nor homocedastic even after a square-root transformation, a nonparametric Kruskall-Wallis ANOVA was used to analyze the effect of locality on the abundance of fragments and successful fragments. Differences between localities were examined using a Nemenyi test for even sample size (Zar 1999).

All statistical analyses were completed with Statistica 6.0 and SPSS 10 software. The $P$-value in all cases was $\alpha=.05$.
RESULTS

\section{Coral Coverage}

Seven species were found at the transects (Table 1), however their presence and contribution to coral cover varied among localities. As shown in Table 1, Pocillopora contributed most of the species (5), whereas Porites (1) and Pavona (1) were minor contributors to species richness. All the reefs exhibited high $(40-50 \%)$ to very high $(50-60 \%)$ live coral cover mainly constructed by Pocillopora spp. Except at Isla Montosa where Pocillopora capitata was the dominant species, Pocillopora damicornis was the main coral builder at all the localities. Features other than corals (algal mat, dead coral cover, sand, and rocks) made up $36 \%$ of the substrate cover at Isla San Agustín to $58 \%$ at La Entrega; algal mat and dead corals contributed largely to the substratum at Isla San Agustín, Jicaral-Chachacual, and La Entrega; and sand and rocks were most important at Isla Cacaluta and Isla Montosa. Unfortunately we lack transect data for La Tijera, but visual surveys show 
TABLE 2

Number of Recovered Tiles, Recruits, and Recruitment Rate per Locality

\begin{tabular}{lcccc}
\hline \hline Locality & $\begin{array}{c}\text { No. of } \\
\text { Recovered Tiles }\end{array}$ & $\begin{array}{c}\text { No. of } \\
\text { Recruits }\end{array}$ & $\begin{array}{c}\text { Recruits } \\
\mathrm{m}^{-2} \mathrm{t}^{-1}\end{array}$ & $\begin{array}{c}\text { Recruit size (mm) } \\
\text { (min/mean/max) }\end{array}$ \\
\hline $\begin{array}{l}\text { La Tijera } \\
\text { Isla San Agustín }\end{array}$ & 33 & 44 & $18.4^{1} \mathrm{a}$ & $0.7 / 2.1 / 16.5$ \\
Jicaral-Chachacual & 32 & 16 & $5.8^{2} \mathrm{~b}$ & $0.7 / 3.4 / 12$ \\
Isla Cacaluta & 60 & 31 & $6.6 \mathrm{~b}$ & $0.5 / 4.4 / 20$ \\
La Entrega & 60 & 7 & $1.5 \mathrm{~b}$ & $1 / 1.9 / 3.5$ \\
Isla Montosa & 60 & 4 & $0.8 \mathrm{~b}$ & $5 / 5.3 / 6$ \\
& 60 & 96 & $20.4 \mathrm{c}$ & $0.5 / 4.9 / 14.5$ \\
\hline
\end{tabular}

Note: Only recruits from tiles collected at the end of the study included. Different letters among sites represent significant differences in recruits (multiple-comparison Nemenyi test, $P<.05$ ).

${ }^{1} 1.08 \mathrm{yr}$.

$20.91 \mathrm{yr}$.

the same community trend (Pocillopora spp. $>$ Porites spp. and Pavona spp.).

\section{Larval Recruitment}

Three to five structures and 44.5 to $83 \%$ of the tiles were recovered from the localities, and 292 corals from two genera were recruited to the settlement tiles. Porites panamensis Verrill constituted 291 corals, and just one Pocillopora sp. was recorded at La Entrega. Ninety-four out of 292 recruits were recorded during monthly tile replacement, whereas the rest of the recruits were recorded on tiles retrieved at the end of the study (Table 2).

The recruitment rate ranged from 0.85 ind $\mathrm{m}^{-2} \mathrm{yr}^{-1}$ at La Entrega to 20.4 ind $\mathrm{m}^{-2} \mathrm{yr}^{-1}$ at Isla Montosa. Recruitment rate varied significantly among localities $(H=63.32$; $\mathrm{df}=5,20 ; P<.01)$, and differences occurred between Isla Montosa and La Tijera, and between those and the rest of the localities. Recruitment rate among Jicaral-Chachacual, Isla Cacaluta, and La Entrega did not show significant differences (Table 2). Larval supply and recruitment conditions affecting settlement vary greatly between localities.

Size-frequency distributions of data for all localities except Isla Cacaluta and La Entrega (because of low number of recruits) are given in Figure 2. All size-frequency distributions were nonnormal and highly skewed to the right; thus all the recruit populations consisted of many small individuals and rela- tively few large ones. Mean colony size varied greatly between sites $(H=12.27 ; \mathrm{df}=3,183$; $P<.01)$. The arithmetic mean of the data suggests that recruits from La Entrega and Isla Cacaluta were the largest and smallest recovered from the area; however, maximum colony size occurred at Jicaral-Chachacual and La Tijera, suggesting variation in recruit size among sites (Table 2).

Bimonthly replacement of tiles started in March 2001, but no recruits were recovered until June 2001 (Figure 3). Considering the time the structures were submerged and the appearance of the first coral recruit in each locality, it took between 5 (La Tijera, Isla San Agustín) and 10 months (La Entrega) before any successful larval settlement, suggesting either a relatively large (up to 5 months) conditioning period of the tiles before settlement, the relative absence of larvae in the water column, or the low chance of encountering a recruit on 2 tiles of 72 at each locality. Recruits found after August 2001 are relatively larger than those that occurred in June 2001, but the trend is not significant (Spearman rank test: $r^{2}=0.8, n=5$, $P=.1)$.

\section{Asexual Recruitment}

Coral fragments were recorded at all localities except La Tijera. No fragments of species other than Pocillopora spp. were recorded across Huatulco. The number of fragments was low at Isla San Agustín (1.3 \pm 2.17 
Isla Montosa

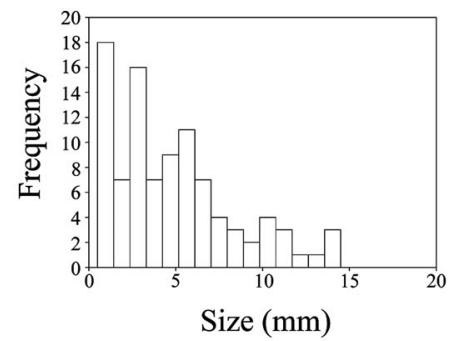

Isla San Agustín

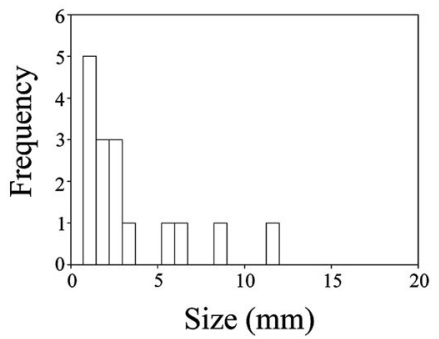

La Tijera

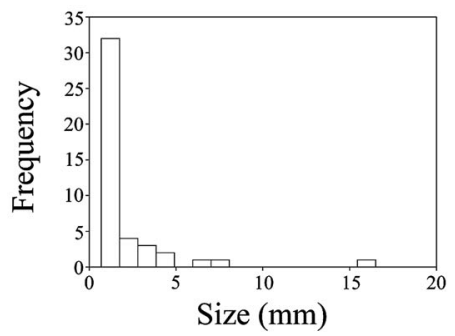

Jicaral-Chachacual

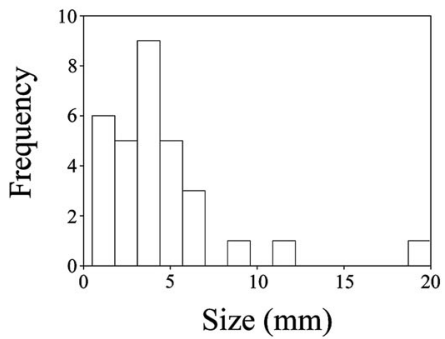

Bahias de Huatulco

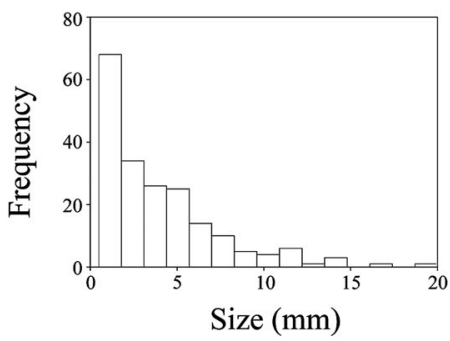

FIGURE 2. Size-frequency (average diameter) distribution of Porites panamensis recruits at studied localities. Bahías de Huatulco $=$ size-frequency distribution data of all localities including Isla Cacaluta and La Entrega. Note different scales on vertical axes.

$[$ mean \pm SD] $)$ and large at La Entrega $(13.15 \pm 30.35)$, whereas Isla Montosa, Isla Cacaluta, and Jicaral-Chachacual had intermediate fragment numbers. Number of fragments was significantly different among localities $(H=51.06 ; \mathrm{df}=5,120 ; P<.01)$. The number of successful fragments varied between $0.3 \pm 0.92$ at Isla San Agustín and $2.75 \pm 2.31$ at Isla Cacaluta, and the rest of the localities had intermediate fragment numbers. Number of successful fragments was significantly different among localities ( $H=48.94$; df $=5,120 ; P<.01)$. However, there is no relationship between the number of fragments and successful fragments. For example, the number of fragments at La Entrega was twice as large as at the second important locality (Jicaral-Cachacual), though the number of successful fragments repre- sented just $16 \%$ of the observed fragments (compared with 24\% at Jicaral-Chachacual). At Isla Montosa, which possessed one-third of the recruitment at La Entrega, successful fragments represented approximately $60 \%$ of the observed fragments (Table 3). It is clear, therefore, that the processes involved in the production of fragments are spatially separate from those affecting the reattachment and survival of fragments in Bahías de Huatulco.

\section{DISCUSSION}

\section{Larval Recruitment}

Previous studies addressing coral recruitment in the eastern Pacific have failed to some extent due to the low number of larval recruits recorded. For example, Birkeland (1977) re- 


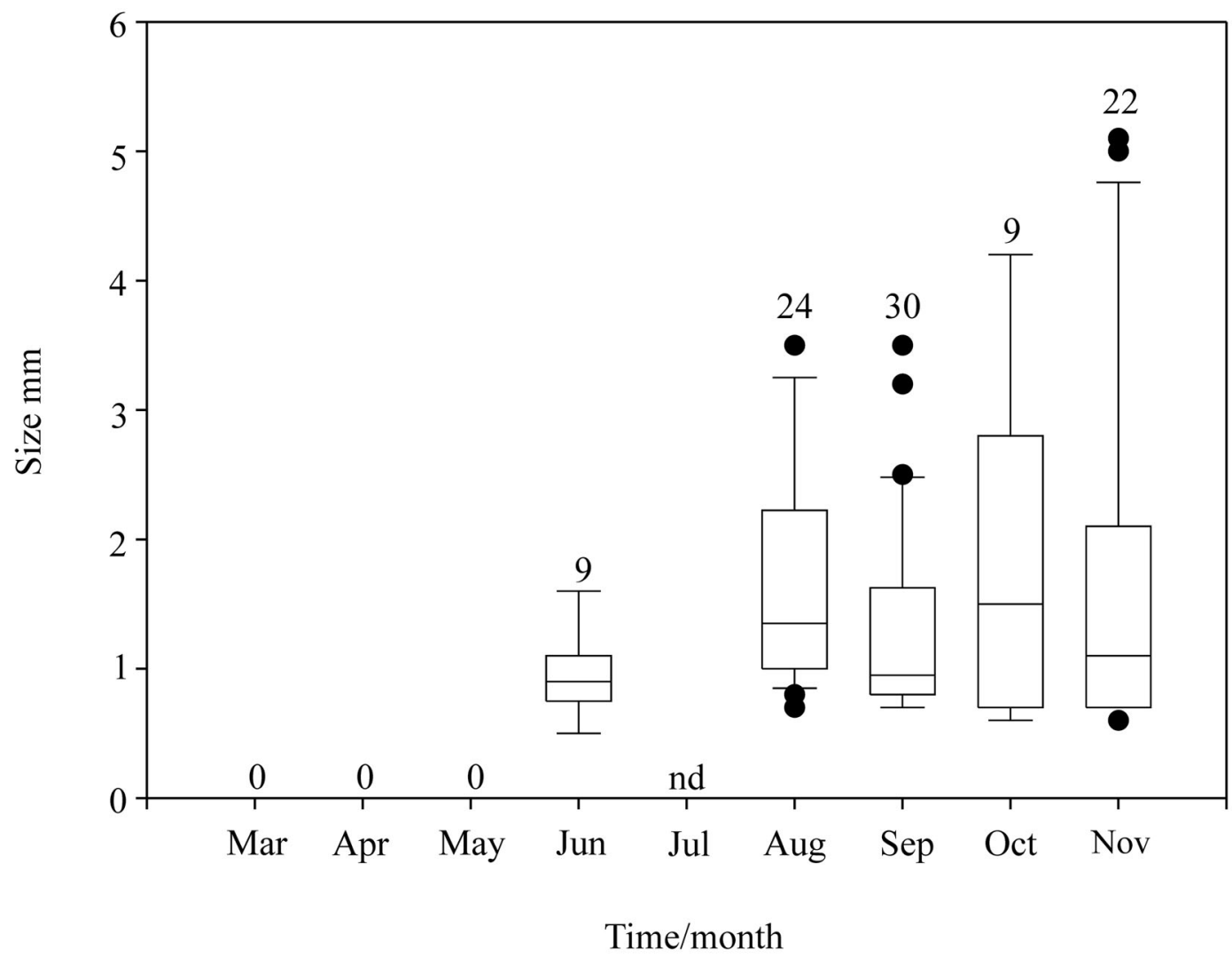

Figure 3. Size (average diameter) of Porites panamensis recruits recovered during all monthly tiles sampled from all sites at Bahías de Huatulco. Numbers above bars refer to number of recruits. nd, tiles not collected.

ported the settlement of two Pocillopora sp. recruits at Taboguilla, Bay of Panama, with a recruitment rate of 1.06 ind $\mathrm{m}^{-2}$ during a 5 yr period; whereas Richmond (1985) reported 11 coral recruits of Pocillopora elegans attached to artificial substrate at the same locality but during a 15 -month period. Medina-Rosas et al. (2005) recovered 25 ahermatypic and hermatypic corals, nine of which belonged to the genus Porites. Therefore, the settlement

TABLE 3

Abundance of Fragments, Successful Fragments, and Importance per Locality

\begin{tabular}{lccc}
\hline \hline Locality & $\begin{array}{c}\text { Fragments per } \mathrm{m}^{2} \\
(\text { mean } \pm \mathrm{SE})\end{array}$ & $\begin{array}{c}\text { Successful Fragments } \\
\left.\text { per } \mathrm{m}^{2} \text { (mean } \pm \mathrm{SE}\right)\end{array}$ & $\begin{array}{c}\text { Successful } \\
\text { Fragments }(\%)\end{array}$ \\
\hline Isla San Agustín & $1.3 \pm 2.2 \mathrm{a}$ & $0.3 \pm 0.9 \mathrm{a}$ & 23.0 \\
Jicaral-Chachacual & $6.7 \pm 7.5 \mathrm{~b}$ & $1.6 \pm 2.2 \mathrm{~b}$ & 24.4 \\
Isla Cacaluta & $5.3 \pm 4.7 \mathrm{c}$ & $2.7 \pm 2.3 \mathrm{~b}$ & 51.0 \\
La Entrega & $13.1 \pm 30.3 \mathrm{~b}$ & $2.1 \pm 4 \mathrm{~b}$ & 16.0 \\
Isla Montosa & $4.5 \pm 1.3 \mathrm{~b}$ & $2.6 \pm 1.9 \mathrm{~b}$ & 58.0 \\
\hline
\end{tabular}

$n=20$ quadrats per locality. Different letters among sites represent significant differences in fragment density (multiplecomparison Nemenyi test, $P<.05)$. 
of 291 Porites panamensis and 1 Pocillopora sp. larvae represents the most important recruitment event ever recorded in the eastern $\mathrm{Pa}$ cific, and to some extent it can be compared with similar events in the Caribbean and high-latitude reefs in the Indo-Pacific (Birkeland 1977, Edmunds 2000, Soong et al. 2003), though still far from the numbers reported at tropical Indo-Pacific reef systems (Dunstan and Johnson 1998, Tamelander 2002, Fox 2004).

In general, previous eastern Pacific recruitment studies have targeted coral communities in Central America and recently Mexico, but there is no firm data to explain either numerical or taxonomic differences in larval recruitment between the study reported here and those already conducted in the eastern Pacific, because Central America and Mexican Pacific localities harbor similar richness, species composition, and reef development (Reyes-Bonilla and López-Pérez 1998, Glynn and Ault 2000). It is unknown to what extent differences in geographic location, geographic extent, settlement material, and time account for the abundance of recruits. It is evident, however, that at least in the eastern Pacific there is a trend: studies restricted to single localities using plastic (i.e., Plexiglas) settlement plates have had the least recruits or none at all, as opposed to those targeting multiple sites using terracotta tiles. Although studying multiple sites intuitively increases the chance of recording recruitment events, terracotta tiles apparently facilitate coral settlement (Harriott and Fisk 1987, Richmond 1997, Medina-Rosas et al. 2005) because its general texture mimics natural substrate conditions, probably allowing a certain degree of biological conditioning and the subsequent settlement of coral spats. Although we lack data to explain unambiguously the recruitment differences among geographic locations and more studies of this kind should be undertaken, differences in recruitment probably resulted from the relatively large spatiotemporal variation in coral reproduction and recruitment (Fadlallah 1983, Harrison and Wallace 1990, Connell et al. 1997, Dunstan and Johnson 1998, and references therein). For example, the main coral builder in the
Huatulco area, P. damicornis (Table 1), is a brooder throughout much of its Indo-Pacific distribution but is a broadcast spawner in the eastern Pacific (Fadlallah 1983, Glynn et al. 1991, Ayre et al. 1997, Richmond 1997, Ayre and Hughes 2000), and its reproductive activity at La Entrega also differs between years (Rodríguez-Troncoso 2006). Porites panamensis is a year-round broadcast spawner in its eastern Pacific distribution (Glynn et al. 1994, Vizcaíno-Ochoa 2003, Mora-Pérez 2005, Rodríguez-Troncoso 2006), but its reproductive activity displays relatively important spatiotemporal variation (Glynn et al. 1994, Mora-Pérez 2005).

Recruitment rate varied between relatively close localities $(1.5-6 \mathrm{~km})$ in the Huatulco area. This is not surprising because studies carried out in tropical and high-latitude temperate reefs have demonstrated that recruitment displays considerable spatial variation (Harrison and Wallace 1990, Connell et al. 1997, Dunstan and Johnson 1998, Soong et al. 2003), even at scales of meters or tens of meters (Tioho et al. 2001, Carlon 2002). Coral recruitment patterns are determined by mechanisms that manifest themselves over a range of spatial scales (Dunstan and Johnson 1998) and directly affect the production, abundance, distribution, and settlement of coral larvae. In our study, there is a significant correlation between Porites panamensis coral coverage data (Table 1) and recruit abundance (Spearman rank test: $r^{2}=0.975, n=5$, $P=.005)$. The relation between coral coverage and number of recruits also suggests, at least in the Huatulco area, that (1) Porites panamensis populations rely mainly on local larval production, and (2) behavior of released larvae is closely related to those local water motion processes that facilitate the retention of the larvae on native reefs. Similar results have been suggested for the species based on histological studies at La Paz, Baja California Sur (Mora-Pérez 2005), Bahia de Banderas (Vizcaíno-Ochoa 2003), La Entrega, Oaxaca (Rodríguez-Troncoso 2006), and Central America (Glynn et al. 1994), suggesting in situ recruitment as the dominant process for maintaining local P. panamensis populations.

Size of recruits suggests that unless 
there are dramatic differences in growth rate among localities, populations of Porites panamensis experience multiple reproductive/ recruitment events through the year. The relatively large differences in degree of development ( 1 to $>200$ corallites per coral spat) and size within localities (Table 1, Figures 2, 3) argues strongly in support of multiple reproductive/recruitment cycles in the area. Similar numbers displayed by the species in $\mathrm{La} \mathrm{Paz}$ (Mora-Pérez 2005), Bahía de Banderas (Vizcaíno-Ochoa 2003), and Central America (Glynn et al. 1994), investigated through histological methods, support our findings. Particularly at La Entrega in the Bahías de Huatulco area, Rodríguez-Troncoso (2006) after a 2-yr histological study (2002-2003 and 2004-2005) reported that $P$. panamensis is reproductively active year-round, although maximum reproductive activity is potentially variable among years.

\section{Asexual Recruitment}

At Bahías de Huatulco no fragments of species other than Pocillopora spp. were recorded. Branching species across all scleractinian groups are more prone to break apart, especially from bioerosion, predation, and water movement (Karlson et al. 1996, Lirman et al. 2001), than massive and encrusting species (Glynn 1990, Reyes-Bonilla and Calderón-Aguilera 1994, Marshall 2000). Commonly, asexual reproduction by fragmentation is the predominant mechanism for maintaining local population sizes, especially in some species of Acropora and Pocillopora (Highsmith 1982, Richmond 1987, Smith and Hughes 1999). Massive species of Porites and faviids, on the contrary, are less prone to breakage (Marshall 2000), therefore reducing the importance of asexual reproduction by fragmentation for maintaining local populations (Reyes-Bonilla and Calderón-Aguilera 1994). At Bahías de Huatulco, fragment formation varied across the area (Table 3 ). In oceanographic terms the Huatulco area is considered to be a relatively homogeneous water body subject to the cyclical influence of the Costa Rica Coastal Current and upwelling from the Gulf of Tehuantepec (Fie- dler 1992, Lluch-Cota et al. 1997), and there is no clear trend suggesting environmental heterogeneity among localities being responsible for differences in fragment production and survival. Nonetheless, relatively large differences exist in natural and human disturbance. In general, disturbance differences occur between relatively disturbed (La Entrega and Jicaral-Chachacual) and undisturbed communities (Isla San Agustín, Isla Cacaluta, and Isla Montosa). Since 1996, there have been no reports of environmental disturbances in the "undisturbed" areas, whereas La Entrega has been continuously and highly disturbed, and recently Jicaral-Chachacual experienced severe coral mortality. La Entrega was affected by the El Niño-Southern Oscillation event in 1987 (Glynn and LeyteMorales 1997), intense public use since the early 1990s (Leyte-Morales 2000), and recurrent dredging of the area at least once a year since the early 1990s (G.E.L.M., pers. obs.). At Jicaral-Chachacual a major disturbance in February 2001 removed $87 \%$ of the coral cover (reduced from $42 \%$ to $5 \%$ ) during which Pocillopora damicornis was selectively removed (López-Pérez et al. 2002, LópezPérez and Hernandez-Ballesteros 2004). Based on these studies, although not conclusive, there is a correlation between disturbance and fragment formation. That is, disturbed communities (La Entrega and Jicaral-Chachacual) possess a relatively large number of fragments compared with undisturbed communities (Isla San Agustín, Isla Cacaluta, and Isla Montosa).

Concurrently, although there is a correlation between disturbance and fragment formation, fragment reattachment and survival (percentage of successful fragments) were spatially separate from the processes involved in fragmentation (i.e., in undisturbed sites fragment reattachment and survival is higher [Table 3]). It has been suggested that fragment survival is a highly complex process in which fragment size, among-species variation in phenotypic plasticity, tissue regeneration ability, susceptibility to disease, corallite morphology, and predator preferences may be considered determining factors in fragment survival (Bruno 1998 and references 
therein). In addition, fragment survival may be highly habitat- and context-specific as well as species-specific (Rogers et al. 1982, Wahle 1983, Heyward and Collins 1985). To date, we lack sufficient data to assess the importance of each of these elements in explaining spatial differences in fragment survival. It is fair to say, however, that the level of disturbance required to generate fragments could also affect fragment survival. It is necessary to state that the relationship between fragments and successful fragments is preliminary and should be considered with caution because we lack information on the time of fragmentation relative to the sampling period (i.e., if close in time, few fragments would be expected to have reattached). Future work on addressing the relationship between fragments and successful fragments must be focused on collecting information on fragmentation (i.e., the disturbance that potentially produced the fragmentation) relative to the sampling period.

Finally, even if our concept of "percentage of successful fragments" is seriously flawed because we lack data on time of fragmentation relative to the sampling period, the most relevant finding regarding asexual reproduction through fragmentation is that the mechanism is important in the dynamics of local populations of Pocillopora spp. at Bahías de Huatulco.

\section{Community Structure}

In the absence of postsettlement mortality and reproduction strategy asymmetries between species, community structure may be mainly driven by the spatiotemporal variability in larval supply and its relation to abundance of adult populations. Under this premise, Bahías de Huatulco sexual and asexual coral recruitment would have been expected to be completely dominated by Pocillopora spp. because these taxa represent $95-99 \%$ of the coral coverage at each local community (Table 1). Based on recruitment results, however, organization of coral communities at Bahías de Huatulco depends on the physical and/or biological interactions affecting the reproduction and the sexual and asexual recruitment and survival of the involved species. Particularly, the sexual and asexual recruitment patterns and potential survival asymmetries displayed by Porites panamensis and Pocillopora spp. in the area are of capital importance in the occurrence of the local coral communities and potentially those of the entire eastern Pacific region.

Evidence from this and other studies suggests that reproduction and recruitment may be highly species-specific and therefore potentially asymmetric. Sexual and asexual reproduction asymmetries in the Huatulco and eastern Pacific areas recently have been recorded in histological studies. Studies conducted at La Paz (P. damicornis [ChávezRomo 2004], P. panamensis [Mora-Pérez 2005]), Bahía de Banderas (P. damicornis, P. panamensis [Vizcaíno-Ochoa 2003]), La Entrega (P. damicornis, P. panamensis [Rodríguez-Troncoso 2004, 2006]), and Costa Rica, Panama, and the Galápagos (P. damicornis, $P$. elegans [Glynn et al. 1991], P. panamensis [Glynn et al. 1994]) found that whereas $P$. panamensis is a species that broods and releases planula larvae year-round, there is no evidence supporting successful sexual reproduction of Pocillopora species in the eastern Pacific area, suggesting relatively high rates of larval recruitment for $P$. panamensis but extremely low rates, if any, for Pocillopora spp. This outcome was tentatively suggested by previous recruitment studies in the area (Birkeland 1977, Wellington 1982, Richmond 1985, Guzmán 1986, Medina-Rosas et al. 2005) but fully supported during our study. For community structure and dynamics, this suggests that recovery of frame-building corals following disturbance is highly speciesspecific; for example, recovery of $P$. panamensis after severe local removal could be relatively fast, but recovery of Pocillopora spp. could be greatly prolonged. We predict, therefore, that nearby and remote new reefs as well as moderately recovered coral communities can be dominated by $P$. panamensis after severe disturbance in the eastern Pacific. Nonetheless, once Pocillopora spp. arrive at this kind of community, or in communities with low to moderate disturbance where patches of Pocillopora spp. were preserved, 
they may contribute greatly to coral coverage via successful fragmentation recruitment, and therefore reef recovery can proceed at a moderately to relatively fast pace after disturbance.

Finally, in numerical terms, recruitment data gathered for the Bahías de Huatulco represent the most important recruitment event ever recorded in the eastern Pacific area. In addition, it allows us to have a deeper knowledge of community structure and dynamics in the Huatulco area in particular and in the entire eastern Pacific region in general. Nonetheless, we need to establish coordinated multidisciplinary and interinstitutional efforts in which genetic, histological, and ecological approaches allow us to unequivocally determine the processes controlling community structure and dynamics in the eastern Pacific. Particularly we need to accurately establish recruitment seasonality and its geographic variation and postsettlement juvenile mortality by monitoring individual recruit histories.

\section{ACKNOWLEDGMENTS}

We thank the Parque Nacional Bahías de Huatulco for permission to work in the area. We thank D. Snyder (University of Iowa) and Balam and Maitreyi (UMar) for proofreading early versions of the manuscript, and H. Reyes-Bonilla (UABCS) and P. Medina (UdG, Puerto Vallarta) for comments and suggestions. Two anonymous reviewers improved the quality of the manuscript.

\section{Literature Cited}

Ayre, D. J., and T. P. Hughes. 2000. Genotypic diversity and gene flow in brooding and spawning corals along the Great Barrier Reef, Australia. Evolution 54:15901605.

Ayre, D. J., T. P. Hughes, and T. P. Standish. 1997. Genetic differentiation, reproductive mode, and gene flow in the brooding coral Pocillopora damicornis along the Great Barrier Reef, Australia. Mar. Ecol. Prog. Ser. 159:175-187.

Benayahu, Y., and Y. Loya. 1984. Substratum preferences and planulae settling of two Red Sea alcyonaceans: Xenia macrospiculata Gohar and Parerythropodium fulvum (Forskal). J. Exp. Mar. Biol. Ecol. 83:249-261.

Birkeland, C. 1977. The importance of biomass accumulations in early stages of benthic communities to the survival of coral recruits. Proc. 3th. Int. Coral Reef Symp. $1: 15-21$.

Carlon, D. B. 2002. Production and supply of larvae as determinants of zonation in a brooding tropical coral. J. Exp. Mar. Biol. Ecol. 268:33-46.

Chávez-Romo, H. E. 2004. Biología reproductiva de Pocillopora damicornis (Linnaeus, 1758) (Scleractinia) en Punta Gaviotas, Bahía de La Paz, Baja California Sur, México. B.S. diss., Universidad Autonoma de Baja California Sur, La Paz.

Connell, J. H., T. P. Hughes, and C. D. Wallace. 1997. A 30-year study of coral abundance, recruitment and disturbance at several scales in space and time. Ecol. Monogr. 67:461-488.

Dollar, S. J., and G. W. Tribble. 1993. Recurrent storm disturbance and recovery: A long-term study of coral communities in Hawaii. Coral Reefs 12:223-233.

Dunstan, P. K., and C. R. Johnson. 1998. Spatio-temporal variation in coral recruitment at different scales on Heron Reef, southern Great Barrier Reef. Coral Reefs 17:71-81.

Edmunds, P. J. 2000. Recruitment of Scleractinia onto the skeletons of coral killed by black band disease. Coral Reefs 19:69-74.

Fadlallah, Y. H. 1983. Sexual reproduction, development and larval biology in Scleractinia corals. Coral Reefs 2:129-150.

Fiedler, P. C. 1992. Seasonal climatologies and variability of eastern tropical Pacific surface waters. NOAA Tech. Rep. 109.

Fox, H. E. 2004. Coral recruitment in blasted and unblasted sites in Indonesia: Assessing rehabilitation potential. Mar. Ecol. Prog. Ser. 269:131-139.

Glynn, P. W. 1990. Coral mortality and disturbances to coral reefs in the tropical eastern Pacific. Pages 55-126 in P. W. Glynn, ed. Global ecological consequences of the 1982-83 El Niño-Southern Oscil- 
lation. Elsevier Oceanography Series, Amsterdam.

Glynn, P. W., and J. S. Ault. 2000. A biogeographic analysis and review of the far eastern Pacific coral reef region. Coral Reefs 19:1-23.

Glynn, P. W., S. B. Colley, C. M. Eakin, D. B. Smith, J. Cortés, N. J. Gassman, H. M. Guzmán, J. B. Del Rosario, and J. S. Feigold. 1994. Reef coral reproduction in the eastern Pacific: Costa Rica, Panamá, and Galápagos Islands (Ecuador). II. Poritidae. Mar. Biol. (Berl.) 118:191-208.

Glynn, P. W., S. B. Colley, N. J. Gassman, K. Black, J. Cortés, and J. L. Maté. 1996. Reef coral reproduction in the eastern $\mathrm{Pa}$ cific: Costa Rica, Panamá and Galápagos Islands (Ecuador). III. Agariciidae (Pavona gigantea and Gardineroseris planulata). Mar. Biol. (Berl.) 125:579-601.

Glynn, P. W., N. J. Gassman, C. M. Eakin, J. Cortés, D. B. Smith, and H. M. Guzmán. 1991. Reef coral reproduction in the eastern Pacific: Costa Rica, Panamá, and Galápagos Islands (Ecuador). I. Pocilloporidae. Mar. Biol. (Berl.) 109:355-368.

Glynn, P. W., and G. E. Leyte-Morales. 1997. Coral reefs of Huatulco, West México: Reef development in upwelling Gulf of Tehuantepec. Rev. Biol. Trop. 45:1033-1047.

Glynn, P. W., D. Lirman, and G. E. LeyteMorales. 1998. First documented hurricane strikes on eastern Pacific coral reefs reveal only slight damage. Coral Reefs $17: 361$.

Gusmán, H. M. 1986. Estructura de la comunidad arrecifal de Isla del Caño, Costa Rica, y el efecto de perturbaciones naturales severas. M.S. diss., Universidad de Costa Rica, San José.

Harriott, V. J., and D. A. Fisk. 1987. A comparison of settlement plate types for experiments on the recruitment of scleractinian coral. Mar. Ecol. Prog. Ser. 37:201208.

Harrison, P. L., and C. C. Wallace. 1990. Reproduction, dispersal and recruitment of Scleractinia corals. Pages 123-207 in Z. Dubinsky, ed. Coral reefs. Ecosystems of the world, vol. 25. Elsevier, Amsterdam.
Heyward, A. J., and J. D. Collins. 1985. Fragmentation in Montipora ramosa: The genet and ramet concept applied to a reef coral. Coral Reefs 4:35-40.

Highsmith, R. C. 1980. Geographic patterns of coral bioerosion: A productivity hypothesis. J. Exp. Mar. Biol. Ecol. 46:177-196.

- 1982. Reproduction by fragmentation in corals. Mar. Ecol. Prog. Ser. 7:207-226.

Hughes, T. P., A. H. Baird, E. A. Dinsdale, V. J. Harriott, N. A. Moltshaniwskyj, S. Pratchett, J. E. Tanner, and B. L. Willis. 2002. Detecting regional variation using meta-analysis and large-scale sampling: Latitudinal patterns in recruitment. Ecology 83:436-451.

Hunter, C. L. 1993. Genotypic variation and clonal structure in coral populations with different disturbance histories. Evolution 47:1213-1228.

Karlson, R. H., T. P. Hughes, and S. R. Karlson. 1996. Density-dependent dynamics of soft coral aggregations: The significance of clonal growth and form. Ecology 77:15921599.

Leyte-Morales, G. E. 2000. Perturbaciones naturales y antropogénicas en las comunidades coralinas de Oaxaca (1977-1998). Resumen. Page 5 in XII Congreso Nacional de Oceanografía. Universidad del Mar, Puerto Ángel, Huatulco.

Lirman, D., P. W. Glynn, and G. E. LeyteMorales. 2001. Combined effects of three sequential storms on the Huatulco coral reef tract, México. Bull. Mar. Sci. 69:267278.

Lluch-Cota, S. E., S. Alvarez-Borrego, E. M. Santamaría-del Angel, F. E. MullerKarger, and S. Hernández-Vázquez. 1997. El Golfo de Tehuantepec y áreas adyacentes: Variación espaciotemporal de pigmentos fotosintéticos derivados de satélite. Cienc. Mar. 23:329-340.

López-Pérez, R. A., and L. M. HernándezBallesteros. 2004. Coral community structure and dynamics in the Huatulco area, western México. Bull. Mar. Sci. 75:453472.

López-Pérez, R. A., L. M. HernándezBallesteros, and T. Herrera-Escalante. 
2002. Cambio en la dominancia de la comunidad arrecifal en Chachacual, Bahías de Huatulco, Oaxaca, México. Cienc. Mar. 6:33-38.

Maida, M., P. W. Sammarco, and J. C. Coll. 1995. Effects of soft corals on scleractinian coral recruitment. I: Directional allelopathy and inhibition of settlement. Mar. Ecol. Prog. Ser. 121:191-202.

Marshall, P. A. 2000. Skeletal damage in reef corals: Relating resistance to colony morphology. Mar. Ecol. Prog. Ser. 200:177189.

Medina-Rosas, P., J. D. Carriquiry, and A. L. Cupul-Magaña. 2005. Recruitment of Porites (Scleractinia) on artificial substrate in reefs affected by the 1997-98 El Niño in Banderas Bay, Mexican Pacific. Cienc. Mar. 31:1-7.

Miller, M. W., E. Weil, and A. M. Szmant. 2000. Coral recruitment and juvenile mortality as structuring factors for reef benthic communities in Biscayne National Park, USA. Coral Reefs 19:115-123.

Mora-Pérez, M. G. 2005. Biología reproductiva del coral Porites panamensis Verrill 1866 (Anthozoa: Scleractinia), en Bahía de La Paz, Baja California Sur, México. M.S. diss., Centro Interdisciplinario de Ciencias Marinas, La Paz.

Mundy, C. N. 2000. An appraisal of methods used in coral recruitment studies. Coral Reefs 19:124-131.

Reyes-Bonilla, H. 2003. Coral reefs of the Pacific coast of México. Pages 331-349 in J. Cortés, ed. Latin American coral reefs. Elsevier, Amsterdam.

Reyes-Bonilla, H., and L. E. CalderónAguilera. 1994. Parámetros poblacionales de Porites panamensis (Anthozoa: Scleractinia), en el arrecife Cabo Pulmo, México. Rev. Biol. Trop. 4:121-128.

Reyes-Bonilla, H., J. D. Carriquiry, G. E. Leyte-Morales, and A. L. Cupul-Magaña. 2002. Effects of the El Niño-Southern Oscillation and the anti-El Niño event (1997-1999) on coral reefs of the western coast of México. Coral Reefs 21:368372.

Reyes-Bonilla, H., and G. E. Leyte-Morales. 1998. Corals and coral reefs of the Puerto
Angel region, west coast of México. Rev. Biol. Trop. 46:679-681.

Reyes-Bonilla, H., and R. A. López-Pérez. 1998. Biogeografía de los corales pétreos (Scleractinia) del Pacifico de México. Cienc. Mar. 24:211-224.

Richmond, R. H. 1985. Variations in the population biology of Pocillopora damicornis across the Pacific. Proc. 5th. Int. Coral Reef Symp. 6:101-106.

. 1987. Energetic relationships and biogeographical differences among fecundity, growth and reproduction in the reef coral Pocillopora damicornis. Bull. Mar. Sci. 4:594-604.

. 1997. Reproduction and recruitment in coral: Critical links in the persistence of reefs. Pages 175-196 in C. E. Birkeland, ed. Life and death of coral reefs. Chapman and Hall, New York.

Rodríguez-Troncoso, A. P. 2004. Caracterización del ciclo reproductivo de Pocillopora damicornis (Linnaeus, 1758), en el arrecife La Entrega, Oaxaca, México. B.S. diss., Universidad del Mar, Puerto Ángel.

. 2006. Ciclo reproductivo de tres especies de corales formadoras de arrecife en Bahía La Entrega, Oaxaca, México. M.S. diss., Universidad Autónoma de Baja California, Ensenada.

Rogers, C. S., T. H. Suchanek, and F. A. Pecora. 1982. Effects of Hurricanes David and Frederic (1979) on shallow Acropora palmata reef communities: St. Croix, U.S. Virgin Islands. Bull. Mar. Sci. 32:532548.

Sammarco, P. W. 1994. Larval dispersal and recruitment processes in Great Barrier Reef corals: Analysis and synthesis. Pages 35-72 in P. W. Sammarco and M. L. Heron, eds. The biophysics of marine larval dispersal. American Geophysical Union, Washington, D.C.

Scheltema, R. S. 1977. Dispersal of marine invertebrate organisms: Paleobiogeographic and biostratigraphic implications. Pages 73-108 in E. G. Kauffman and J. E. Hazel, eds. Concepts and methods of biostratigraphy. Dowden, Hutchinson and Ross, Stroudsberg, Pennsylvania.

Smith, L. C., and T. P. Hughes. 1999. An 
experimental assessment of survival, reattachment and fecundity of coral fragments. J. Exp. Mar. Biol. Ecol. 235:147164.

Soong, K., M. Chen, C. Chen, C. Dai, T. Fan, J. Li, and H. Fan. 2003. Spatial and temporal variation of coral recruitment in Taiwan. Coral Reefs 22:224-228.

Tamelander, J. 2002. Coral recruitment following a mass mortality event. Ambio 31:551-557.

Tioho, H., M. Tokeshi, and S. Nojima. 2001. Experimental analysis of recruitment in a scleractinian coral at high latitude. Mar. Ecol. Prog. Ser. 213:79-86.
Vizcaíno-Ochoa, V. E. 2003. Biología reproductiva de tres especies de corales formadores de arrecifes en Bahía Banderas, México. M.S. diss., Universidad Autónoma de Baja California, Ensenada.

Wahle, C. M. 1983. Regeneration of injuries among Jamaican gorgonians: The role of colony physiology and environment. Biol. Bull. (Woods Hole) 165:778-790.

Wellington, G. M. 1982. Depth zonation of corals in the Gulf of Panamá: Control and facilitation by resident reef fishes. Ecol. Monogr. 52:223-241.

Zar, J. H. 1999. Biostatistical analysis. Prentice Hall, Englewood Cliffs, New Jersey. 
